\title{
Faculty Member Performance Evaluation And Salary Pricing Modeling For Lebanese Private Universities
}

Viviane Y. Naïmy, (E-mail: vnaimy@ndu.edu.lb), Notre Dame University, Lebanon

\begin{abstract}
The purpose of this paper is to present an objective evaluation model that can be applied on private Lebanese universities. A set of interrelated equations is established in order to reflect objectively the results of the faculty member's performance evaluation. A simulation application is presented to illustrate the particularities of this model and its impact on the salary "pricing".
\end{abstract}

\subsection{Introduction}<smiles>[AlH2]</smiles>

hile performance evaluation is not simple, faculty members' evaluation is an opportunity to motivate effective job performance. It is a tool that can enhance the management of a University, and it is also a process that allows faculty members to be recognized for good performance and provided with recommendations for improvement. Since performance evaluation is communication between faculty member and University supervisors, it is an extremely important supervisory responsibility with far-reaching consequences for both the University eminence and the faculty member career. Thus, faculty member evaluation should lead to a certain form of promotion to be translated into a salary adjustment.

However, Lebanese private universities suffer from a serious lack of objectivity in evaluating their faculty members' performance or deciding about their salary increases. Hence, they require a consistent evaluation model far from subjectivity and prejudice.

The purpose of this paper is to propose an objective and flexible performance evaluation model that can be tailored with respect to the budget constraints of each university and to its own evaluation criteria and norms. Consequently, the determination of the final salary will be automatically set and justified without biased individual interventions.

\subsection{The Model}

\subsection{Purpose Of The Model}

The purpose of this model is first to provide private Lebanese universities with an evaluation system that can be easily adapted and modified according to their evaluation standards and principles and secondly to assist the decision maker in adjusting and tweaking faculty members' salaries.

\subsection{Structure Of The Model}

Since the final endeavor of the model is to reorganize the salary in order to reflect objectively the results of any performance evaluation, we have built the final salary from four components/variables as follows:

1. Basic Salary

2. Transport expenses

3. Personal points

4. Seniority 


\subsection{Definition Of Variables}

\subsubsection{Basic Salary, "Base"}

In order to determine the amount of Base, the model suggests the structure of a function represented by 5 different factors. Factors can be considered as constant amounts or they can be allocated a certain weight to be considered with respect to the details and facts of each factor.

The following table depicts the particularities of these factors:

\begin{tabular}{|c|c|c|c|}
\hline Structure of the Base & $\#(2)$ & $\mathbf{W}(3)$ & $\begin{array}{l}\text { Amount } \\
\text { in } \$(4)\end{array}$ \\
\hline 1. Basis for starting salary BSS (1) & & & $\begin{array}{l}\text { Constant } \\
\mathrm{K}(1)\end{array}$ \\
\hline 2. Number of years of full-time teaching at the University level (TE) & $\mathrm{x}$ & $\mathrm{y}$ & $=\mathrm{x} * \mathrm{y} *(1)$ \\
\hline 3. Practical experience (PE), & $\mathrm{x}$ & $\mathrm{y}$ & $=\mathrm{x} * \mathrm{y} *(1)$ \\
\hline 4. Experience in Administrative Assignment (AA) & $\mathrm{x}$ & $\mathrm{y}$ & $=\mathrm{x} * \mathrm{y} *(1)$ \\
\hline 5. Research and Publications (RP) & & & $=\operatorname{Sum}(\mathrm{a}: \mathrm{f})$ \\
\hline a. Reprint of Refereed Research Paper (RRR) & $\mathrm{x}$ & $\mathrm{y}$ & $=x^{*} y^{*}(1)$ \\
\hline b. Refereeing of Research Papers (RRP) & $\mathrm{x}$ & $\mathrm{y}$ & $=x^{*} y^{*}(1)$ \\
\hline c. Supervision of MS/MA thesis or Ph.D. dissertations (SD) & $\mathrm{x}$ & $\mathrm{y}$ & $=\mathrm{x} * \mathrm{y} *(1)$ \\
\hline d. Textbook or Book Publications (TP) & $\mathrm{x}$ & $\mathrm{y}$ & $=x^{*} y^{*}(1)$ \\
\hline $\begin{array}{r}\text { e. Research activities }(R A) \text { such as conferences, seminars, exhibitions, } \\
\text { publications of non-refereed papers and the like }\end{array}$ & $\mathrm{x}$ & $\mathrm{y}$ & $=x^{*} y^{*}(1)$ \\
\hline $\begin{array}{r}\text { f. Miscellaneous }(M), \text { professional recognition, Merit, awards, } \\
\text { professional listings and the like }\end{array}$ & $\mathrm{x}$ & $\mathrm{y}$ & $=\mathrm{x} * \mathrm{y} *(1)$ \\
\hline Total Base & & & $\operatorname{Sum}(1: 5)$ \\
\hline
\end{tabular}

(1) BSS can be determined according to the country economic conditions regarding basic salaries, and to the university standards. The model proposes at the outset a clear definition of this factor, i.e., a starting amount should be set. This constant amount will serve as a starting point for the computation of the value of the four other variables.

(2) \# means number of years or number of research and publications.

(3) $\mathrm{W}$ means the weight (in \%) to be allocated for each variable. This weight is set according to the University's strategy. The higher the weight, the higher the amount to be paid for the faculty member. With respect to the budget constraints of the university, the highest weight can be allocated for the most challenging variable, and the university can objectively, in this case, manipulate the ceiling and the floor of the Base.

(4) The last column starting point 2 (i.e. TE) represents the result of the weighted number of years or publications times the constant amount already defined in (1).

Consequently, the corresponding function can be written as follow ${ }^{1}$ :

Base $=\mathrm{K}+f(\mathrm{TE}, \mathrm{PE}, \mathrm{AA}, \mathrm{RP})$

Where:

$\mathrm{TE}=\#_{\mathrm{TE}} * \mathrm{~W}_{\mathrm{TE}} * \mathrm{~K}$

$\mathrm{PE}=\#_{\mathrm{PE}} * \mathrm{~W}_{\mathrm{PE}} * \mathrm{~K}$

$\mathrm{AA}=\#_{\mathrm{AA}} * \mathrm{~W}_{\mathrm{AA}} * \mathrm{~K}$

$\mathrm{RP}=\#_{\mathrm{RP}} * \mathrm{~W}_{\mathrm{RP}} * \mathrm{~K}=\#_{\mathrm{RRR}} * \mathrm{~W}_{\mathrm{RRR}} * \mathrm{~K}+\#_{\mathrm{RRP}} * \mathrm{~W}_{\mathrm{RRP}} * \mathrm{~K}+\#_{\mathrm{SD}} * \mathrm{~W}_{\mathrm{SD}} * \mathrm{~K}+\#_{\mathrm{TP}} * \mathrm{~W}_{\mathrm{TP}} * \mathrm{~K}+\#_{\mathrm{RA}} * \mathrm{~W}_{\mathrm{RA}} * \mathrm{~K}+\#_{\mathrm{M}} * \mathrm{~W}_{\mathrm{M}} * \mathrm{~K}$

\footnotetext{
${ }^{1}$ For more details please refer to Excel sheet "Salary Simulation".
} 
The Base should be directly indexed to the $\mathrm{CPI}^{2}$, that is, at the end of the year, the cumulated average percentages of the CPI will be applied and added to the Base $^{3}$.

\subsubsection{Transport expenses}

At the end of 2002, a Lebanese National convention has set a daily transport expenses at US\$ 4.6 or LBP 7000. This sum should be an independent item from the other components.

\subsubsection{Personal points, "PP"}

Personal points constitute the core of the faculty member performance evaluation. According to our performance evaluation model, PP are divided into (1) points number and (2) points value in USD.

(1) Points number are a linear function of a set of variables to be defined by each university, such as:

1. Competence: $\mathrm{c}$,

2. Skills: $\mathrm{s}$,

3. Experience: e,

4. Publications: $\mathrm{p}$,

5. Academic activities: aa,

6. Social achievements: sa,

7. Integrity: i,

8. Others (such as political sympathies, communal belongings, etc)

It is worth mentioning that those variables are considered and counted one year after the faculty member has joined the private university. Therefore, there is no correlation between this function and function (1) defined above.

Points Number $=\varphi(\mathrm{c}, \mathrm{s}, \mathrm{e}, \mathrm{p}, \mathrm{aa}, \mathrm{sa}, \mathrm{i})$.

Where,

Points Number $=\mathrm{m}_{1} \mathrm{c}+\mathrm{m}_{2} \mathrm{~s}+\mathrm{m}_{3} \mathrm{e}+\mathrm{m}_{4} \mathrm{p}+\mathrm{m}_{5} \mathrm{aa}+\mathrm{m}_{6} \mathrm{sa}+\mathrm{m}_{7} \mathrm{i}$

and $\mathrm{m}_{1}, \mathrm{~m}_{2}, \ldots, \mathrm{m}_{7}$ represent the corresponding elasticity to each variable.

The weight of $\mathrm{m}_{1}, \mathrm{~m}_{2}, \ldots, \mathrm{m}_{7}$ can be determined by each university. However, and based on our survey covering a small sample chosen from the top 5 universities ${ }^{4}$ located in Lebanon, we propose the following weights.

\begin{tabular}{|c|c|c|c|c|c|c|c|c|}
\hline & $\mathbf{m}_{\mathbf{1}}$ & $\mathbf{m}_{\mathbf{2}}$ & $\mathbf{m}_{\mathbf{3}}$ & $\mathbf{m}_{\mathbf{4}}$ & $\mathbf{m}_{\mathbf{5}}$ & $\mathbf{m}_{\mathbf{6}}$ & $\mathbf{m}_{\mathbf{7}}$ & $\mathbf{m}_{\mathbf{8}}^{\mathbf{5}}$ \\
\hline Observation $^{\mathbf{6}}$ & 0.125 & 0.01 & 0.2 & 0.4 & 0.1 & $\mathbf{0}$ & 0.01 & 0.15 \\
\hline Weight Proposition & 0.17 & 0.13 & 0.14 & 0.22 & 0.14 & 0.1 & 0.1 & $\mathbf{0}$ \\
\hline
\end{tabular}

\footnotetext{
${ }^{2}$ Consumer Price Index. The selected CPI will be an average between the Lebanese Central Bank figures and the ones of the Administration Centrale de la Statistique.

${ }^{3}$ Inflation rates cannot be applied on the whole salary, it should only concern the first basic part since Base helps to cover basic needs (food, clothing, accommodation etc.)

${ }^{4}$ American University of Beirut (3 full-time faculty members), Université Saint Joseph (2 full-time faculty members), Notre Dame University (1 full-time faculty member), Lebanese American University (1 full-time faculty member), and Balamand University (1 full-time faculty member).

${ }^{5} \mathrm{~m} 8$ does not correspond to any variable defined in this study. It is considered as miscellaneous variable (such as special connections in the right places, political affairs, etc.)

${ }^{6}$ According to interviews done with full-time faculty members belonging to the above mentioned universities.
} 
Values of $m_{1}$ to $m_{8}$ corresponding to our survey (observation line) are computed on the basis of a weighted average values. Our model weight proposition follows a normal and objective distribution taking into consideration the sociological and economic constraints of Lebanon as well as the academic quality equilibrium allocation.

Each point number, i.e., c, s, e, p, aa, sa, and i will be by itself a function of a set of conditions, once realized, the full-time faculty member will be automatically credited with the corresponding points number. However, a ceiling of points should be set for each variable and this ceiling should be the same for all of them. In our model we propose a ceiling of $300^{7}$ points. This ceiling can be modified with respect to the internal strategy of the university.

\begin{tabular}{|c|c|c|c|c|}
\hline Variables & Conditions $^{\mathbf{8}}$ & Points number & $\begin{array}{c}\text { Weight } \\
\text { Proposition }\end{array}$ & $\begin{array}{c}\text { Maximum Weighted } \\
\text { Points to be credited }\end{array}$ \\
\hline $\mathrm{c}$ & & 300 & 0.17 & 51 \\
\hline $\mathrm{s}$ & & 300 & 0.13 & 39 \\
\hline $\mathrm{e}$ & & 300 & 0.14 & 42 \\
\hline $\mathrm{p}$ & & 300 & 0.22 & 66 \\
\hline $\mathrm{aa}$ & & 300 & 0.14 & 42 \\
\hline $\mathrm{sa}$ & & 300 & 0.1 & 30 \\
\hline $\mathrm{i}$ & & 300 & 0.1 & 30 \\
\hline
\end{tabular}

The total weighted points to be credited is 300 . This number is considered to be the maximum number that can be reached by any faculty member, with respect to the budget constraint of the concerned university. This budget constraint is based on the maximum additional sum of money that can be attained. Assuming a value of USD 20 per point, the maximum additional amount cannot exceed in this case USD $6000^{10}$.

Accordingly,

$\mathrm{PP}=\Sigma\left(\mathrm{m}_{1} \mathrm{c}+\mathrm{m}_{2} \mathrm{~s}+\mathrm{m}_{3} \mathrm{e}+\mathrm{m}_{4} \mathrm{p}+\mathrm{m}_{5} \mathrm{aa}+\mathrm{m}_{6} \mathrm{sa}+\mathrm{m}_{7} \mathrm{i}\right) *$ Point Value

The advantage of this model resides in the fact that performance evaluation can be measured personally by the faculty member and reflected objectively into his salary without ambiguity or individual favoritism. Therefore, any salary increase will depend on the achievement and effort deployed by the faculty member for the benefit of his or her university academic progress. Unfortunately, such an objective evaluation system is completely absent from the Lebanese universities programs.

\section{$\underline{\text { 2.3.4 Link Between Points Number And Rank }}{ }^{11}$}

The model has set a perfect positive correlation between the accumulated number of points and the promotion or the rank of the faculty member. The common factor between accumulated points and the rank is the 300 number. This common point preserves the coherence and the consistency of this evaluation model.

The greater the number of points accumulated by the faculty member during his/her career, the faster the promotion from a rank to another will be granted to him/her. The corresponding accumulated points number to each rank are proposed in the table below:

\footnotetext{
7 The selection of the number " 300 " has been set for an average and fair private university.

${ }^{8}$ The university can set the appropriate conditions to be fulfilled by the faculty member.

${ }^{9}$ The weight of each variable corresponds to the above values of the 7 parameters $(\mathrm{m} 1, \mathrm{~m} 2, \mathrm{~m} 3, \ldots, \mathrm{m} 7)$, i.e, $51=300 * 0.17$

${ }^{10}$ This ceiling does not take into consideration other administrative responsibilities assumed by the faculty member such as the responsibility of being Dean, chairperson, etc.

${ }^{11}$ Rank is defined as the promotion from Instructor to Lecturer, Senior Lecturer, Assistant Professor, Associate Professor and to Professor.
} 


\begin{tabular}{|l|c|c|}
\hline \multicolumn{1}{|c|}{ Rank } & $\begin{array}{c}\text { Corresponding weighted } \\
\text { points }\end{array}$ & $\begin{array}{c}\text { Accumulated weighted } \\
\text { Points }\end{array}$ \\
\hline Instructor & 25 & 25 \\
\hline Lecturer & 50 & 75 \\
\hline Senior Lecturer & 50 & 125 \\
\hline Assistant Professor & 50 & 175 \\
\hline Associate Professor & 50 & 225 \\
\hline Professor & 75 & 300 \\
\hline Total & 300 & \\
\hline
\end{tabular}

The determination of these points is subject to the university discretion. However, the total number should always be in conformity with the above defined point number.

\subsubsection{Seniority, $\mathrm{S}$}

The model suggests a certain compensation for seniority. This compensation should be independent from the promotion of the faculty member and at the same time directly correlated to the accumulated number of points calculated according to equation (6). In other terms, if the faculty member is still serving the university year after year but without any academic improvement, he will not be promoted but he will be compensated for his/her seniority with respect to his/her last accumulated points number. Consequently, this seniority is reflected in his/her salary via this equation:

$S=\Upsilon(P N, Y)$

Where

$P N=m_{1} c+m_{2} s+m_{3} e+m_{4} p+m_{5} a a+m_{6} s a+m_{7} i$

And

$\mathrm{Y}=$ number of years*Value ${ }^{12}$ of each year expressed in USD

\subsection{Simulation (Please Refer To Excel Sheets)}

\subsection{Hypothesis:}

\section{1- Case of Dr. Happy}

Dr Happy is a full time faculty member since January 1999.

He is very competent and devoted. He has published 3 articles in a refereed journal.

He has 7 years of experience in Financial Institutions.

$\mathrm{He}$ is very active and has contributed to the organization of 4 conferences within the University and he got an award in recognition of excellence in research.

\section{2- Case of Dr. Satisfied}

Dr. Satisfied is a full time faculty member since January 1999.

$\mathrm{He}$ is a good teacher. He was not able to publish. His professional experience is limited. He is not very active.

\section{Question:}

With respect to the above faculty member evaluation modeling, what will be the annual salary of Mr. Happy and Mr. Satisfied at the end of 2002? (Make sure to present the salary structure according to its 4 components).

\footnotetext{
${ }^{12}$ Each university can attribute the corresponding value that can fit its budget constraint.
} 
Assume an inflation rate of $5 \%$, value per point $=\$ 10$, value of a one-year seniority $=1 \mathrm{USD}$.

\subsection{Simulation results:}

\begin{tabular}{|r|r|}
\hline Salary Distribution of Dr Happy (per month in USD) & $\mathbf{2 0 0 2}$ \\
\hline Basic Salary & $1,575.00$ \\
\hline Inflation amount & 75.60 \\
\hline Transport expenses & 121.33 \\
\hline Personal points & $1,771.00$ \\
\hline Seniority & 531.30 \\
\hline Total Salary & $\mathbf{4 , 0 7 4 . 2 3}$ \\
\hline
\end{tabular}

\section{$\underline{\text { Dr. Happy's PN }}$}

Points Number $\left(\mathrm{m}_{1} \mathrm{c}+\mathrm{m}_{2} \mathrm{~s}+\mathrm{m}_{3} \mathrm{e}+\mathrm{m}_{4} \mathrm{p}+\mathrm{m}_{5} \mathrm{aa}+\mathrm{m}_{6} \mathrm{sa}+\mathrm{m}_{7} \mathrm{i}\right)$

\begin{tabular}{|l|l|l|l|l|l|l|l|}
\hline & $\mathrm{m}_{1}$ & $\mathrm{~m}_{2}$ & $\mathrm{~m}_{3}$ & $\mathrm{~m}_{4}$ & $\mathrm{~m}_{5}$ & $\mathrm{~m}_{6}$ & $\mathrm{~m}_{7}$ \\
\hline Proposition & 0.17 & 0.13 & 0.14 & 0.22 & 0.14 & 0.1 & 0.1 \\
\hline
\end{tabular}

\begin{tabular}{|c|c|c|c|c|c|c|}
\hline c & $\mathbf{s}$ & e & $\mathbf{p}$ & aa & sa & $\mathbf{i}$ \\
\hline 51 & 39 & 42 & 66 & 42 & 30 & 30 \\
\hline
\end{tabular}

$\begin{array}{lrrrrrrr}\text { Ceiling points number } & 300.00 & 300.00 & 300.00 & 300.00 & 300.00 & 300.00 & 300.00 \\ \text { to be filled } & 200 & 150 & 200 & 180 & 150 & 150 & 200 \\ \text { Weighted personal points } & 34 & 19.5 & 28 & 39.6 & 21 & 15 & 20 \\ \text { Total personal points } & \mathbf{1 7 7 . 1} & & & & & & \end{array}$




\begin{tabular}{|r|r|}
\hline Salary Distribution of Dr Satisfied (per month in USD) & $\mathbf{2 0 0 2}$ \\
\hline Basic Salary & $1,150.00$ \\
\hline Inflation amount & 55.20 \\
\hline Transport expenses & 121.33 \\
\hline Personal points & $1,257.00$ \\
\hline Seniority & 377.10 \\
\hline Total Salary & $\mathbf{2 , 9 6 0 . 6 3}$ \\
\hline
\end{tabular}

\section{Dr Satisfied's PN}

Points Number $=\left(m_{1} c+m_{2} s+m_{3} e+m_{4} p+m_{5} a a+m_{6} s a+m_{7} i\right)$

\begin{tabular}{|l|l|l|l|l|l|l|l|}
\hline & $\mathrm{m}_{1}$ & $\mathrm{~m}_{2}$ & $\mathrm{~m}_{3}$ & $\mathrm{~m}_{4}$ & $\mathrm{~m}_{5}$ & $\mathrm{~m}_{6}$ & $\mathrm{~m}_{7}$ \\
\hline Proposition & 0.17 & 0.13 & 0.14 & 0.22 & 0.14 & 0.1 & 0.1 \\
\hline
\end{tabular}

\begin{tabular}{|c|c|c|c|c|c|c|}
\hline c & $\mathbf{s}$ & e & $\mathbf{p}$ & aa & sa & $\mathbf{i}$ \\
\hline 51 & 39 & 42 & 66 & 42 & 30 & 30 \\
\hline
\end{tabular}

\begin{tabular}{lrrrrrrr}
$\begin{array}{l}\text { Ceiling points number } \\
\text { to be filled }\end{array}$ & 300.00 & 300.00 & 300.00 & 300.00 & 300.00 & 300.00 & 300.00 \\
\hline Weighted personal points & 200 & 150 & 100 & 100 & 80 & 50 & 200 \\
Total personal points & 34 & 19.5 & 14 & 22 & 11.2 & 5 & 20 \\
\hline
\end{tabular}

\subsection{Simulation Summary}

With respect to the above simulation results, Dr. Happy should be promoted to the rank of Associate Professor while Dr. Satisfied should be demoted.

\subsection{Conclusion}

The purpose of this paper was to present an objective evaluation model that can be applied on private Lebanese universities. This model has established a set of equations interrelated where the dependant variables were divided into four categories constituting the structure of the final salary and the independent variables were properly customized in way to fit each private university with respect to its endogenous and exogenous constraints. The particularity of this model resides in its flexibility in terms of "pricing" and in its objectivity in terms of performance evaluation (promotion, salary adjustment, etc). The main benefit of this model is that it avoids individual interventions during the evaluation process and reduces subjectivity to the bare minimum in a country where the promotion and the determination of salaries become subject to personal contacts and unprofessional assessment. 


\subsection{References}

1. Aleamoni, L.M. (1987). Student rating myths versus research facts. Journal of Personnel Evaluation in Education, 1, 111-119.

2. Amatora, M. (1954). Teacher rating by younger pupils. Journal of Teacher Education, 5 (2), 149-152.

3. American Educational Research Association (1953). Second Report of the Committee on the Criteria of Teacher Effectiveness. Journal of Educational Research, 46, 641-658.

4. American Federation of Teachers (1996). Making standards work. Washington, D.C.: author.

5. Bergman, J. (1980). Peer evaluation of university faculty. College Student Journal, 14 (3), Part 2, 1-21.

6. Berman, P. \& McLaughlin, M.W. (1978). Federal programs supporting educational change, vol. viii: Implementing and sustaining innovations (R-1589/8-HEW). Santa Monica, CA: Rand Corporation.

7. Blackburn, R. \& Clark, M. (1975). An assessment of faculty performance: Some correlates between administrators, colleagues, students and self ratings. Sociology of Education, 48, 242-256.

8. Carroll, J. (1981). Faculty self evaluation. In J. Millman (Ed.), Handbook of teacher evaluation (pp. 180200). Beverly Hills, CA: Sage.

9. Cederblom, D. \& Lounsbury, J. (1980). An investigation of user-acceptance of peer evaluations. Personnel Psychology, 33, 567.

10. Elbow, P. (1986). Embracing contraries: Explorations in learning and teaching. New York: Oxford University Press.

11. Haertel, E.H. (1987). Toward a national board of teaching standards: The Stanford Teacher Assessement Project. Educational Measurement: Issues and Practices, 6 (1), 23-24.

12. Medley, D.M. \& Coker, H. (1987). The accuracy of principals' judgments of teacher performance. Journal of Educational Research, 80, 242-247.

13. Medley, D.M., Coker, H. \& Soar, R.S. (1984). Measurement-based evaluation of teacher performance: An empirical approach. New York: Longman.

14. Murphy, J. (1987). Teacher evaluation: A comprehensive framework for supervisors. Journal of Personnel Evaluation in Education, 1, 157-180.

15. Nisbett, R.E. \& Ross, L. (1980). Human inference: Strategies and shortcomings of social judgment. Englewood Cliffs, NJ: Prentice-Hall.

16. Perry, R., Abrami, P. \& Leventhal, L. (1979). Educational seduction: The effect of instructor expressiveness and lecture content on student ratings and achievement. Journal of Educational Psychology, 71, 107-116.

17. Peterson, K.D. (1989c). Costs of school teacher evaluation in a career ladder system. Journal of Research and Development in Education, 22 (2), 30-36. 